Kohl: a Journal for Body and Gender Research

Vol. 4, No. 1 (Summer 2018)

\title{
The Employments of the Punitive System in Zionism's Exploitation of Homosexuality
}

\author{
Musa Shadeedi
}

\begin{abstract}
:
The Zionist discourse has taken male homosexuality as its subject since the beginning of the settlement campaigns. This article traces the transformations of this discourse across time, its relation with political changes, and its usage of the prevailing punitive system in Arabic-speaking countries derived from English and French colonial penal codes. The article studies male homosexuality as a pivotal axis used by Zionist discourse towards the creation of pinkwashing, which in turn uses the suffering of homosexuals in the Eastern prisons to legitimize the suffering of the Palestinian people (gay, straight, and of all sexual orientations) in the prisons of the occupation. So how is the punitive institution discursively used for these ends? In the relation between homosexual bodies and the punitive system in the Middle East, how did changes over time produce pinkwashing scenarios? The article attempts to follow these changes since the British mandate over Palestinian land and before the declaration of the occupying state. At the time, homosexual bodies were confined in Israeli prisons, charged with "same-sex behavior," and homosexuality was defined as an "Eastern character," contrary to what is promoted by the contemporary pinkwashing rhetoric.
\end{abstract}


In 2005, Israel cooperated with American executive directors supportive of the Zionist entity in working on the "Brand Israel" marketing campaign that targeted men between the ages of 18 and 34. The Jewish Daily Forward newspaper reported that the campaign aimed to portray Israel as a "relevant and modern" entity, and used gay men to create that image. ${ }^{1}$ This was the beginning of the formulation of the pinkwashing campaign. In 2010, the Israeli news website Yedioth Ahronoth reported that the Tel Aviv Tourism Board had spent nearly $\$ 90$ million on a campaign that was trying to market the city as a "global destination for gay holidays."2 The Ministry of Tourism and the Israeli Consulates supported the campaign and financed pro-Israeli films at gay film festivals in the United States. The Israeli Prime Minister Benjamin Netanyahu referred to the Middle East as the place where "women are stoned, gays are hanged, and Christians are persecuted"3 as to not limit the campaign to advertisements, media, and film festivals, and to complement it with political speeches. The rhetoric thus exploited the suffering of homosexuals in Arabic-speaking countries because of penal systems to minimize the suffering of the Palestinian people (gay, straight, and of all sexual orientations) in Israeli prisons, and at the hands of the Zionist occupation in general.

The Global Movement against Israeli occupation describes the phenomenon of the use of human rights discourse by the occupation's institutions as "pinkwashing." This denominator references deliberate strategies that attempt to cover both the violations of Palestinian people's rights, and Zionist and imperialist occupation, through hiding behind an image of modernity, exploitative of gay rights, as a façade. Thus, pinkwashing portrays Israel as the Middle Eastern gays' only haven and as the only state that protects and tolerates homosexuality. In return, it depicts Palestinians as violent homophobes who force gay people to flee to Tel Aviv. ${ }^{4}$ Despite the Zionist entity's portrayal of Tel Aviv as a home for Palestinians homosexuals, many academics have warned against the whitewashed image aimed at the international community, as many of the Zionist politicians are actually homophobic, as evidenced by the migration of many Israeli gays to different cities in northern Europe. ${ }^{5}$

In 2017, Tel Aviv took advantage of the arrest of 33 homosexuals in Egypt following the raising of the rainbow flag in Cairo during a concert of the Lebanese band Mashrou' Laila, and organized a "solidarity" party, considered pinkwashing by the BDS campaign in Lebanon. Zionist pinkwashing uses the punitive system in Arabic-speaking countries in its discourse to portray us as "backwards," in contrast to Israelis deemed "progressive" because of their "sympathy" to homosexuality as a cause.

1 Schulman, S. 2011. "Israel and 'Pinkwashing." The New York Times, November 22. Available at: https://www.nytimes.com/2011/11/23/opinion/pinkwashing-and-israels-use-of-gays-as-a-messaging-tool.html

2 Sadeh, D. 2010. "Campaign branding Tel Aviv gay destination underway." Ynetnews, July 21. Available at: https://www.ynetnews.com/articles/0,7340,L-3922524,00.html

${ }^{3}$ https://www.nytimes.com/2011/11/23/opinion/pinkwashing-and-israels-use-of-gays-as-a-messaging-tool.html

4 The usage of pinkwashing has expanded to encompass diluting crimes other than those of the Zionist entity; local pinkwashing aims at branding politicians and organizations as progressive to belittle or hide their role and complicity with institutions of oppression. This article does not claim that the practice is exclusive to the Zionist entity, but its scope is limited to that discussion.

${ }^{5}$ Abu-Assab, N. 2014. "Decolonising' Queer Migration." Queer Migration and Mobilities Workshop. The Department of Sociology, Lund University, Sweden. 
The evidence presented in this article indicates that the patterns of the Zionist discourse's usage of homosexual practices in Palestinian society have changed since the British Mandate over Palestine, and that it was influenced by the many political shifts in the region. This article attempts to shed light on the changes that benefited the Israeli political goals and interests, and on methods that were employed, in addition to the contemporary usage of pinkwashing, to justify the suffering of an entire people under occupation.

In his article "An Oriental vice Representations of sodomy in early Zionist discourse," Ofri llany investigates Hebrew literature on homosexuality in Palestine since the British Mandate period (1920-1948), i.e., before the declaration of Israel as a state. It is noteworthy that the most important Hebrew medical and criminology texts printed in Palestine in the 1930s, 1940s, and 1950s portrayed oriental characters engaging in male homosexual practices in one form or another. For example, criminology scholar Carl Frankenstein, who studied homosexuality thoroughly at the Hebrew University in his book Youth Neglect published in 1947, emphasized the tendency to engage in homosexual practices among men in Nablus in his book Youth Neglect, published in 1947. He also claimed that "the crime of homosexuality is common" and that "sexual crimes" are more prevalent among young people of Eastern backgrounds than those of European ones. ${ }^{6}$

A description of "gay clubs" appears in an article published by Iton Meyuchad in January 1934, entitled "In the Tel Aviv Underworld."7 As an attempt to explain the spread of the "anomaly" in Jewish society, she states that "these anomalies are more common in the East. You'll see young men who make love in public, not in Jaffa alone, but they also go to Tel Aviv to celebrate."8 This is one example of many Hebrew articles and literature that confirm that homosexuality was pertinent and acceptable in Palestinian society, but was considered an "epidemic" source of danger to the Zionist society in Hebrew literature at the time, which completely opposes Tel Aviv's contemporary claim of "solidarity" with the gay community. What is portrayed as support to gay men today is an attempt to prevent mass solidarity with the Palestinian people.

To that effect, the occupying entity has modified its policies: the police of the new-found Israeli occupying state arrested all suspected homosexuals, using policies that complement the criminalization of "abnormal sexual practices" in the British Mandate Act before 1948. And on September 5, 1949, in an article entitled "Many Indecent Acts Were Performed in Tel Aviv Tonight," the newspaper Yedioth Ahronoth9 reported a crackdown on a public bathroom on Gruzenberg Street one night, with the police finding a "33-year-old man, resident of King George V Street, sodomizing a 16-year-old boy." At the same time, the police arrested four young men in the public parks of Tel Aviv "for not being able to explain to the police their lying

\footnotetext{
6 Frankenstein, C. 1947. Youth Neglect: What is It, How it Came About and its Signs [Azuvat Hano'ar: Mahuta, hithavuta usimaneiha]. Jerusalem: Szald Children and Youth Institute, p 140.

7 Meyuchad, I. 1934. "In the Tel Aviv Underworld." Iton Meyuchad, January 31.

$8 \mathrm{lbid}$.

9 1949a. "Many Indecent Acts Were Performed in Tel Aviv Tonight." Yediot Ahronoth, September 5.
} 
down on the ground at such late hour." Several weeks later, the newspapers reported that a few young people broke into an apartment on Mapu Street and handed the owner over to the police, claiming that he "offered them sodomy."10 This history resonates with what is happening today in Egypt and other Arabicspeaking countries in terms of the usage of the punitive system to target homosexual bodies.

In the following years, however, the arrests markedly declined as Haim Cohen rose to the post of AttorneyGeneral and recommended that homosexual practices be prosecuted only if committed in public or with a minor. ${ }^{11}$ This decline coincided with the emergence of the sexual rights movement in Nordic countries, origin of the majority of those holding high authority positions in the occupying state and who wanted to maintain close relations with their countries of origin. ${ }^{12}$

In the first Palestinian revolt in 1987, the Israeli intelligence services needed informants to suppress the popular uprising. One of the methods used was to gather information about Palestinian individuals who practiced what could be considered unacceptable by their own kin, such as premarital sex, drug use, theft, homosexuality, etc., to blackmail them into working for the occupation. The Palestinian left was receptive to this method back then, which gave rise to a stigma against homosexual practices in Palestinian society by linking it to infiltration and espionage. ${ }^{13}$ This constituted another use of Palestinian homosexual bodies by the Zionist intelligence and control apparatuses to consolidate the occupation and its punitive system, and to suppress the struggles of Palestinian people seeking to refute the occupation.

The discourse changed tremendously before the start of the second Palestinian intifada, as it took the shape of a campaign against the Palestinian Authority and used American media as its playground. Israeli and pro-Israeli "activists" blogged that homosexuals "oppressed" by their governments and in their countries only find refuge in "democratic" Israel, contrary to their previous rhetoric. Homosexuality had been considered an eastern trait despised and feared by Israel, and taken as an excuse to assert the state of apartheid. A series of interviews with these "gay refugees" recounted tales of terrible torture by members of the Palestinian Authority.

In August 20, 2002, The New Republic published an article entitled Refugee Status, written by Yossi Klein Halevi, about a few Palestinians who fled to Israel because it gave them the "freedom" to live as homosexuals, in contrast to Arab land. The article describes grotesque torture claimed to have happened to Palestinian gays at the hand of the Palestinian authority. A month later, on September 13, the American Yale Herald published an article by Jewish Davi J. Bernstein entitled "Palestinians are Suffering under Arafat" that used the same terms to describe the "hideous" atrocities of the Palestinian Authority; it also

10 1949b. "Youngsters Take Revenge on a Sodomy Perpetrator." Yediot Ahronoth, September 26.

11 Yonai, Y. 1998. "The Law Regarding Homosexuality - Between History and Sociology [Hebrew]." Mishpat uMimshal 4: 531-586.

12 This article did not thoroughly research the reasons behind the decline in the number of arrests.

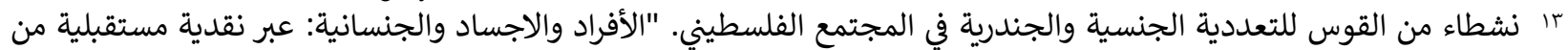

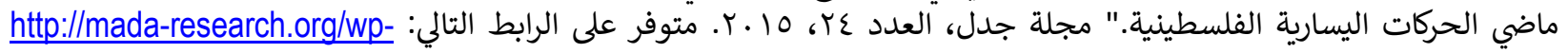
content/uploads/2015/11/JDL24-4-Qaws.pdf 
hailed Israel as "the only country in the Middle East where homosexuals can live in freedom."14 In fact, the undoubted usage of the homosexuality as a recurrent theme in the Israeli discourse against the struggle of the Palestinian people is a common trope, apparent in the above articles as well as the literature analyzed by llany. From portraying them as "practitioners of homosexuality" in the past, the discourse shifted to shaming them as "enemies of the freedom of homosexuality" in the present. This discourse makes use of prisons in two ways: by historically incarcerating those engaging in same-sex practices in Israeli prisons, and recently, by recruiting gay men under the guise of "protection," all the while exploiting their presence in Palestinian prisons.

Nevertheless, Israeli authorities tried to deport these gay "refugees" and return them to their Palestinian cities, which prompted Israeli gay groups to express their outrage with the decision and accuse the authorities of causing deaths. On March 6, 2003, BBC published an article titled "'Death Threat' to gay Palestinians," deeming Palestinian land as unsafe for gay people on the one hand, and Israel as a "sanctuary" on the other, in an attempt to depict the occupation as a cradle for people marginalized and displaced by that same occupation.

Pro-Israeli American Jews launched a Zionist attack that claimed to "expose" the Palestinian Authority's "persecution" of homosexuals, out of fear that the Palestinian cause would be supported by American gays - as Joseph Massad explains in Desiring Arabs. ${ }^{15}$ As a result of these changes, pinkwashing appeared as a practice.

The Zionist discourse denouncing (Palestinian) homosexuality in the past and the Zionist discourse against homophobes (Palestinians and/or Arabs) today are one and the same. It aims to legitimize occupation and apartheid, and to serve the Zionist project that violates the rights of an entire people, gay and straight alike. From the use of homosexuality by Israeli prisons in the past, homosexuality became a tool of recruitment for the occupation, with the intelligence service forcing gay people to spy against their freedom and their people. The radical change in the pre-second Palestinian intifada period exploited the treatment of gay people in Palestinian prisons to justify Zionist apartheid's treatment of Palestinians in Israeli prisons. Therefore, the punitive system plays a major role in the production of pinkwashing. The pinkwashing campaign today, in turn, intersects with all of the above, as it uses homosexuality to solidify the occupation and mobilize gay people against their own people and freedom, while exploiting the suffering experienced by queer bodies to justify the suffering of all bodies under occupation.

${ }^{14}$ http://archive.li/Oue4t\#selection-329.362-329.435

15 Massad, J. 2007. Desiring Arabs. Chicago: University of Chicago Press. 